\title{
Cutaneous Leishmaniasis among Syrian Refugees in Jordan: a Retrospective Study
}

\author{
Leishmaniose cutanée chez des réfugiés syriens en Jordanie : étude rétrospective
}

\author{
Z. Sami Amr · K. Kanani · B. Shadfan · R. Bani Hani
}

Received: 8 August 2018; Accepted: 18 January 2019

(C) Société de pathologie exotique et Lavoisier SAS 2019

\begin{abstract}
The aim of this study is to investigate cutaneous leishmaniasis (CL) among Syrian refugees residing in Jordan. A total of 558 Syrian refugee patients were clinically diagnosed with cutaneous leishmaniasis during 2010-2016. For each patient, sex, age, location, and number of lesions were recorded. Of the total $558 \mathrm{CL}$ cases among Syrian refugees, $514(92.1 \%)$ were classified as imported, $14(2.5 \%)$ as locally acquired infection, and $30(3.4 \%)$ of cases unclassified due to lack of information. By gender, 306 (55\%) were males and $252(45 \%)$ were females. Ages ranged between 1 and 78 years $(17.3 \pm 16.3)$, with the age group $1-10$ years $(48.2 \%)$ being the most affected group. The face was the most affected (171 cases, 30.6\%), followed by the hands and arms in 95 cases $(17 \%)$, while lesions on the legs were observed in 69 cases $(12.4 \%)$, and 65 cases $(11.6 \%)$ on the trunk. The number of lesions ranged from 1 to $5(1.39 \pm$ $0.985)$ on the face, 1 to $3(1.32 \pm 0.898)$ on the trunk, 1 to 17 $(1.5 \pm 41.39)$ on the arms, and 1 to $5(1.5 \pm 1.473)$ on the legs. Extensive efforts should be undertaken by the health officials in Jordan to confine the spread of this disease by strengthening surveillance, diagnosis of new cases, proper treatment of all cases, and entomological surveys for the presence of the vector sandflies as well as the reservoir hosts within the refugee camps. Most cases were considered as imported $(92.1 \%)$ and require immediate attention at the port of entry.
\end{abstract}

Keywords Cutaneous leishmaniasis - Leishmania tropica . Syrian refugee $\cdot$ Refugee camps $\cdot$ Jordan $\cdot$ Western Asia

\footnotetext{
Z. Sami Amr $(\bowtie) \cdot$ R. Bani Hani

Department of Biology, Jordan University of Science and

Technology, P. O. Box 3030, Irbid, Jordan

e-mail : amrz@just.edu.jo

K. Kanani · B. Shadfan

Parasitic and Zoonotic Diseases Division,

Ministry of Health, Amman, Jordan
}

Résumé L'objectif de ce travail est l'étude de la leishmaniose cutanée (LC) chez des réfugiés syriens résidant en Jordanie. La LC a été cliniquement diagnostiquée chez 558 réfugiés syriens entre 2010 et 2016 . Les données suivantes ont été enregistrées pour chaque patient : le sexe, l'âge, le nombre et l'emplacement des lésions. Sur ce total de 558 cas de LC, $514(92,1 \%)$ sont classés comme importés, 14 (2,5\%) comme localement contractés et $30(3,4 \%)$ n'ont pas été classifiés en raison d'un manque d'information; 306 patients (55\%) sont des hommes et $252(45 \%)$ des femmes. Les âges vont de 1 à 78 ans $(17,3 \pm 16,3)$, le groupe de $1-10$ ans $(48,2 \%)$ est le plus touché. Les lésions sont les plus nombreuses sur le visage ( $171 \mathrm{cas}, 30,6 \%$ ), suivi par les mains et les bras dans 95 cas (17\%), les jambes dans 69 cas $(12,4 \%)$ et le tronc dans 65 cas $(11,6 \%)$. Le nombre de lésions varie de $1-5(1,39 \pm 0,985)$ sur le visage, de $1-3(1,32 \pm 0,898)$ sur le tronc, de $1-17(1,5 \pm 41,39)$ sur les bras et de $1-5(1,5 \pm$ 1,473) sur les jambes. Les agents de santé en Jordanie doivent mettre en œuvre les mesures nécessaires pour circonscrire la propagation de cette maladie en renforçant le suivi, le diagnostic des nouveaux cas, le traitement approprié de tous les cas et la surveillance entomologique des phlébotomes vecteurs et des hôtes réservoirs dans les camps de réfugiés. La plupart des cas sont considérés comme importés $(92,1 \%)$ et nécessitent des soins immédiats à la porte d'entrée.

Mots clés Leishmaniose cutanée $\cdot$ Leishmania tropica . Réfugiés syriens $\cdot$ Camps de réfugiés $\cdot$ Jordanie $\cdot$ Asie du Sud-Ouest

\section{Introduction}

During the civil war in Syria that started in 2010, thousands of Syrians fled to neighboring countries (Jordan, Lebanon, and Turkey). Estimated numbers of Syrian refugees in Jordan reach up to 1.4 million, whereas less than $20 \%$ of the 
refugees are living in refugee camps [10]. At the early stages of the conflict, many refugees settled in large cities, but later many were placed in refugee camps in Mafraq (Za'taree camp) and Zaraq (Azraq camp) governorates. Both camps were not known previously to be active foci for cutaneous leishmaniasis.

Cutaneous leishmaniasis (CL) is an endemic parasitic disease in the Middle East and North Africa [3]. Two species of parasites causing CL are endemic in Jordan and Syria, Leishmania major and Leishmania tropica, with several species of sandflies serving as vectors $[2,8,13]$. The so-called anthroponotic CL due to Leishmania tropica is known to be established and circulating in the north-western Syrian governorates such as Aleppo and Idlib [17].

Sharara \& Kanj [14] reviewed the growing epidemics of infectious diseases including cutaneous leishmaniasis in Syria, Lebanon, and Jordan to understand the impact of human displacement during war. It was pointed out on the increase of cutaneous leishmaniasis cases in Syria with 41,000 reported cases in 2013 as compared to about 30,000 cases in 2008 [4,5]. Increase of cutaneous leishmaniasis among Syrian refugees has already been reported in Lebanon with 996 cases from 2000 to 2012 compared to 948 cases for 2012 only $[1,16]$. Two studies also evaluated the prevalence of CL among Syrian refugees in Nizip, Turkey, and southern Turkey, with 62 and 76 cases, respectively $[7,15]$. A comparative study on the clinical features of CL among Syrian refugees and Turkish patients in Sanliurfa, southern Turkey was undertaken [18]. They showed that the duration of the disease among Syrian refugees was shorter than that among Turkish patients. They also found that the number of lesions among Syrian patients was greater than Turkish patients. Between 2009 and 2015, 88 cases of CL caused by L. tropica were diagnosed at the molecular level among Syrian refugees from Gaziantep [12].

The present investigation discusses epidemiological and clinical characteristics of $\mathrm{CL}$ among Syrian refugees residing in Jordan.

\section{Materials and methods}

All active CL cases among refugees of Syrian nationality at any age and gender from 2010 to 2016 were included in this study. An active CL case was defined as a person showing clinical signs of long-lasting skin lesion (papule, nodule, or ulcerative lesion) typically on uncovered parts of the body of more than 1 week duration, and any laboratory confirmed CL case. Non-Syrian nationality CL cases and all old scars of CL cases were excluded.

Data were extracted from the records at the Parasitic and Zoonotic Diseases Division at the Ministry of Health from 2010 to 2016. This division conducts the malaria control program in the country and is also responsible for the surveillance and control of vector-borne and zoonotic diseases. Medical doctors visited refugee camps, and data from other health centers all over the country were included. For each patient, the following variables were evaluated: sex, age, location of the cutaneous lesions, monthly distribution, number of lesions, lag time between entry into Jordan and approximate date of appearance of the lesions, lag time between approximate date of appearance of lesions, and date of reporting to the Ministry of Health. CL cases among Syrian refugees were classified as imported or local cases according to the lag time between entry into Jordan and approximate date of onset of the lesion. All lesions which appeared before arrival in Jordan or within 2 months after arrival were classified as imported.

Nine samples (six from infected Syrian refugees and three from uninfected Jordanians) were analyzed by two PCR amplifications of the ribosomal internal transcribed spacer 1 (ITS-1) gene as described by Hijjawi et al. [6] at Pasteur Institute, Tunisia.

Results were statistically analyzed using chi-square test to calculate the p-value and Professional Statistics Package (SPSS Version 17, SPSS Inc., Chicago Ill.) to calculate mean, standard deviation and $95 \%$ confidence intervals for sex (male $v s$ female), age groups (by range), and site and number of lesions.

\section{Results}

\section{Clinical results}

Site and number of lesions varied among diagnosed cases (Fig. 1). The face was the most affected body area $(171$ cases, 30.6\% $)(P<0.05) \quad(P=0.001$, CI $=$ $0.3249-0.3858$ ), followed by the hands and arms in 95 patients $(17 \%)$, while lesions on the legs were observed in 69 patients $(12.4 \%)$, and 65 cases $(11.6 \%)$ on the trunk. The number of lesions ranged from 1 to $5(1.39 \pm 0.985)$ on the face, 1 to $3(1.32 \pm 0.898)$ on the trunk, 1 to $17(1.5 \pm$ $41.39)$ on the arms, and 1 to $5(1.5 \pm 1.473)$ on the legs. Three hundred and twenty-five patients $(58.2 \%)$ had a single lesion, while 233 patients $(41.8 \%)$ had multiple lesions (More than one lesion) (Table 1). Overall, the number of lesions per patient ranged between 1 and $22(1.3 \pm 1.03)$.

Among the patients with multiple lesions, eight (1.4\%) had lesions on the face, trunk, feet, and arms; five $(0.9 \%)$ on the legs, face, and arms; one (0.2) on the trunk, arms, and legs; one on the trunk and the arms $(0.2 \%) ; 12(2.2 \%)$ on the arms and legs; $15(2.7 \%)$ on the face and the trunk; 31 $(5.6 \%)$ on the face and arms; five $(0.9 \%)$ on the trunk and arms; $13(2.25)$ on the trunk and legs; and $28(5 \%)$ on the legs and the arms. 


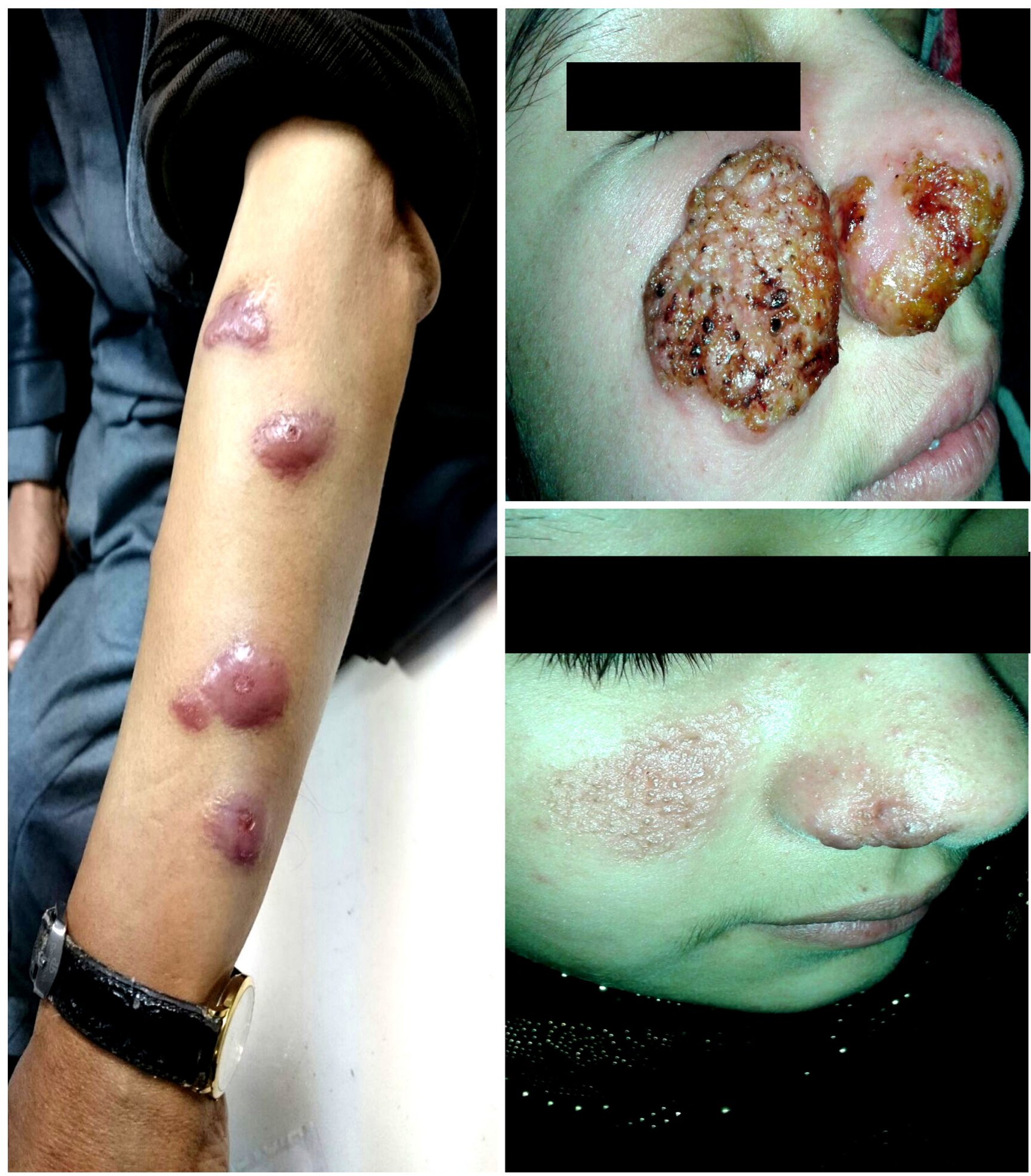

Fig. 1 Single and multiple lesions observed among Syrian refugees infected with Leishmania in Jordan / Lésions simples et multiples observées chez les réfugiés syriens atteints de leishmaniose en Jordanie

\section{PCR results}

Six of the nine samples were identified as positive for L. tropica. The remaining three were negative.

\section{Epidemiological results}

A total of 558 Syrian refugee patients were clinically diagnosed with CL during 2010-2016 (Table 2). The highest 
Table 1 Age groups, gender, and number of lesions among Syrian refugees infected with cutaneous leishmaniasis / Groupes d'âge, sexe et nombre de lésions chez les réfugiés syriens atteints de leishmaniose cutanée

\begin{tabular}{|lllll|}
\hline Age group (years) & \multicolumn{3}{l}{ Sex } & \multicolumn{2}{l|}{ Number of lesions } \\
\cline { 2 - 5 } & Male (\%) & Female (\%) & Single lesion (\%) & Multiple lesions (\%) \\
\hline $1-10$ & $104(18.6)$ & $165(29.6)$ & $159(28.5)$ & $110(19.7)$ \\
$11-20$ & $56(10.1)$ & $67(12)$ & $76(13.6)$ & $79(8.4)$ \\
$21-30$ & $31(5.6)$ & $23(4)$ & $29(5.2)$ & $25(4.5)$ \\
$31-40$ & $26(4.7)$ & $24(4.3)$ & $29(5.2)$ & $21(3.8)$ \\
$41-50$ & $17(3)$ & $15(2.7)$ & $14(2.5)$ & $7(1.9)$ \\
$51-60$ & $8(1.4)$ & $10(1.8)$ & $5(0.9)$ & $3(0.5)$ \\
$61-70$ & $6(1.1)$ & $2(0.4)$ & $2(0.4)$ & $2(0.4)$ \\
$71-78$ & $4(0.7)$ & $0(0)$ & $325(58.2)$ & $233(41.8)$ \\
Total & $252(45.2)$ & $306(54.8)$ & & \\
\hline
\end{tabular}

\begin{tabular}{|ll|}
\hline $\begin{array}{l}\text { Table } 2 \text { Cases of cutaneous leishmaniasis among Syrian refu- } \\
\text { gees in Jordan / Cas de leishmaniose cutanée chez les réfugiés } \\
\text { syriens en Jordanie }\end{array}$ \\
\hline Year & No. of diagnosed cases \\
\hline 2010 & 12 \\
2011 & 6 \\
2012 & 12 \\
2013 & 106 \\
2014 & 80 \\
2015 & 187 \\
2016 & 155 \\
Total & 558 \\
\hline
\end{tabular}

number of cases was diagnosed in 2015, while the lowest was in 2011. By gender, $306(55 \%)(20 \pm 16.91)$ were males and $252(45 \%)(18.5 \pm 16.9)$ were females, and there was a significant difference between the two groups $(P<$ $0.05)(P=0.022, \mathrm{CI}=0.5070-0.5898)$. Ages ranged between 1 and 78 years $(17.3 \pm 16.3)$, with the age group $1-10$ years $(48.2 \%)$ being the most affected group compared to other age groups $(P<0.05)(P=0.001$, CI $=$ 0.74507-0.81407) (Table 1).

By region, most cases were reported from Azraq refugee camp in Zaraq Governorate, followed by Zata'ree refugee camps in Mafraq (Table 3, Fig. 2). The approximate time period between the first appearance of skin lesion and date of reporting to $\mathrm{MOH}$ was 5.75 months ( 0.5 to 22 months). The monthly distribution of the cases was evaluated according to the onset of the appearance of lesions and the date of notification. Of the $558 \mathrm{CL}$ cases among Syrian refugees, $514(92.1 \%)$ were imported, $14(2.5 \%)$ were locally acquired, and $30(3.4 \%)$ were unclassified due to lack of information on date of lesion onset or date of arrival into Jordan. There was seasonal variation in the distribution of
Table 3 Distribution of cutaneous leishmania cases among Syrian refugees according to region or governorate / Distribution des cas de leishmaniose cutanée chez les réfugiés syriens en fonction de la région

\begin{tabular}{|lll|}
\hline Region/Governorate & No. of cases & \% \\
\hline Ajlune & 1 & 0.2 \\
Amman & 87 & 15.6 \\
Aqaba & 36 & 6.5 \\
Balqa & 20 & 3.6 \\
Karak & 8 & 1.4 \\
Mafraq (Za'taree camp) & 72 & 12.9 \\
Northern Jordan Valley & 29 & 5.2 \\
Southern Jordan Valley & 44 & 7.9 \\
Tafilah & 1 & 0.2 \\
Zaraq (Azraq camp) & 260 & 46.6 \\
Total & 558 & 100 \\
\hline
\end{tabular}

cases, the peak number of cases started to appear during the cold months of the year from November to January (Fig. 3). The least number of diagnosed cases were among refugees residing in Ajlune and Tafilah.

\section{Discussion}

Our results showed that most cases $(92.1 \%)$ were considered as imported. There is a seasonal distribution of CL, peaking during the cold months of the year. And the latest version of the report on cases of the first appearance of cutaneous leishmaniasis increases the risk of establishment and spread of $\mathrm{CL}$ in Syrian refugee camps and among Syrian refugees.

This study highlights the burden of cutaneous leishmaniasis among Syrian refugees in Jordan. Leishmaniasis is an endemic disease in the Middle East and poses a public health 


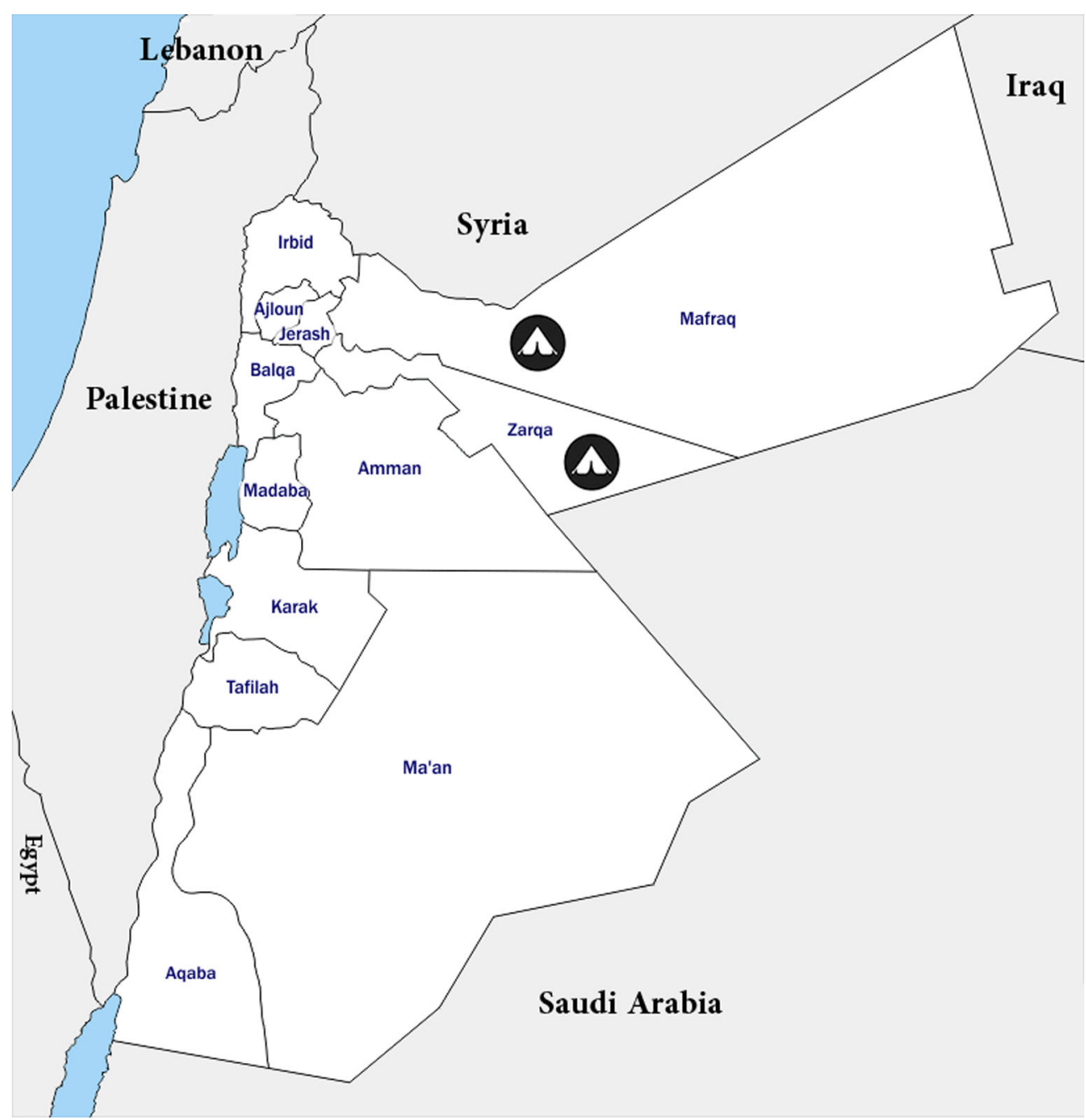

Fig. 2 Map of Jordan showing governorates and Syrian refugee's campsites / Carte de la Jordanie avec localisation des gouvernorats et des camps de réfugiés syriens

issue among the Syrian refugees in neighboring countries $[2,11,15,18]$. With the influx of Syrian refugees to Jordan, new foci of the disease have been established in Mafraq and Azraq refugee camps. Both areas are known to be leishmania-free, with no records of human cases over the past 50 years; however, recent entomological studies confirmed the presence of Phlebotomus major syriacus, Phlebotomus papatasi, and Phlebotomus sergenti from the Azraq area and Phlebotomus alexandri, P. papatasi, and P. sergenti from Al Marazah near Mafraq [9]. Phlebotomus papatasi has been incriminated as the main vector for $L$. major in Jordan and the Middle East [9]. Thus, new foci for the disease transmission may evolve over time and cause spread of the disease among the local population, especially L. tropica.

Results showed seasonal distribution of first appearance lesions, peaking during the cold months of the year, and late detection or reporting of cases after the first appearance of cutaneous leishmaniasis lesions, increasing the risk of estab- lishment of new foci and spread of L. tropica in Syrian refugee camps and among the host community of Syrian refugees.

The disease was found to affect all age groups; however, children (1-10 years old) were the most affected. This is in agreement with studies among Syrian and Turkish patients in southern Turkey [18] and among Syrian refugees in Lebanon [10].

In this study, the head and face region was the most affected body area (181 cases, 30.6\%). Similar results were obtained by Turan et al. [18] and Saroufim et al. [16], whereas $223(32.55 \%)$ and $43 \%$ of Turkish and Syrian patients have lesions on the head-neck region, respectively [16,18]. Inci et al. [7] reported that $16 \%$ and $36 \%$ of the Syrian refugees and Turkish citizens whom their age group ranged from 1 to 20 years have a single and multiple lesions, respectively. In this study, single and multiple lesions were observed among $42.1 \%$ (235) and 28.1\% (189) of examined patients aged $1-20$ years old, respectively. 


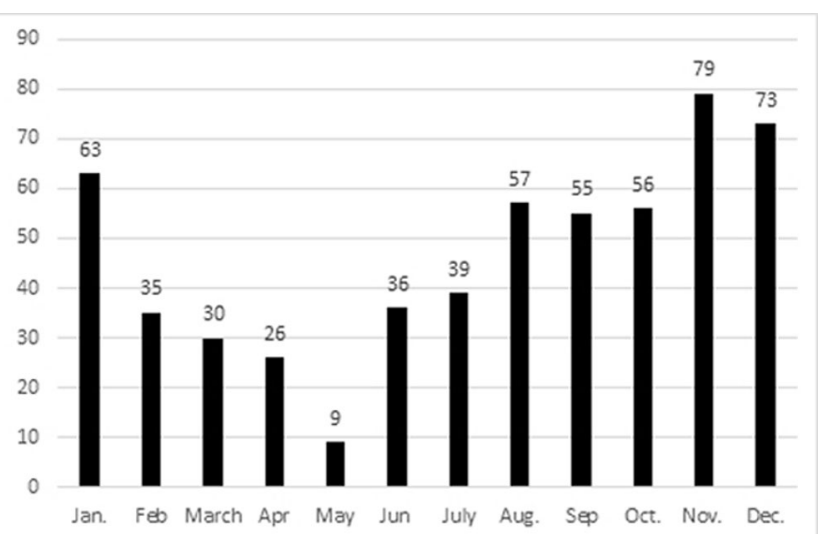

Fig. 3 Number of cases by the month of notification of skin lesions among Syrian refugees in Jordan / Nombre de cas par mois de notification des lésions cutanées chez les réfugiés syriens en Jordanie

By sex, the disease was slightly more prevalent among males rather than females (54.8 and 45.2\%). In contrast, Inci et al. [7] found that CL was more common among females than males, and they attributed this to a high percentage of females among refugees, whereas males either stayed in Syria or died because of the conflict.

It should be kept in mind that not all cases of CL among Syrian refugees were documented due to the movement of many refugees in cities as Amman and Zarqa. In addition, some cases will go unnoticed since some families fail to report to clinics or health centers. The limitations of this study are that it represents a retrospective study with possible underreporting or potential underreporting. Other limitations include the definition of clinical and imported cases, as well as the absence of parasitological confirmation for all cases, since positive identification of $L$. tropica is based only on six patients.

Extensive efforts should be undertaken by the health officials in Jordan to confine the spread of this disease by strengthening surveillance, diagnosis of new cases, proper treatment of all cases, and entomological surveys for the presence of the vector sandflies as well as the reservoir hosts within the refugee camps.

Acknowledgment Our thanks are extended to Dr. Riad Benismail, Pasteur Institute, Tunisia, for PCR study of specimens.

Conflicts of interests: The authors do not have any conflict of interest to declare.

\section{References}

1. Alawieh A, Musharrafieh U, Jaber A, et al (2014) Revisiting leishmaniasis in the time of war: the Syrian conflict and the
Lebanese outbreak. Int J Infect Dis 29:115-9. doi: 10.1016/j.ijid.2014.04.023. Epub 2014 Oct 24

2. Al-Salem WS, Pigott DM, Subramaniam K, et al (2016) Cutaneous Leishmaniasis and conflict in Syria. Emerg Infect Dis 22:931-3. doi: 10.3201/eid2205.160042

3. Du R, Hotez PJ, Al-Salem WS, Acosta-Serrano A (2016) Old World cutaneous leishmaniasis and refugee crises in the Middle East and North Africa. PLoS Negl Trop Dis 10:e0004545. doi: 10.1371/journal.pntd.0004545. eCollection 2016 May

4. Haddad N, Saliba H, Altawil A, et al (2015) Cutaneous leishmaniasis in the central provinces of Hama and Edlib in Syria: vector identification and parasite typing. Parasit Vectors 8:524. doi: 10.1186/s13071-015-1147-0

5. Hayani K, Dandashli A, Weisshaar E (2015) Cutaneous leishmaniasis in Syria: clinical features, current status and the effects of war. Acta Derm Venereol 95:62-6. doi: 10.2340/00015555-1988

6. Hijjawi N, Kanani KA, Rasheed M, et al (2016) Molecular diagnosis and identification of Leishmania species in Jordan from saved dry samples. Biomed Res Int 2016:6871739. doi: 10.1155/2016/6871739. Epub 2016 Jun 15

7. Inci R, Ozturk P, Mulayim MK, et al (2015) Effect of the Syrian civil war on prevalence of cutaneous leishmaniasis in southeastern Anatolia, Turkey. Med Sci Monit 21:2100-4. doi: 10.12659/MSM.893977

8. Janini R, Saliba E, Kamhawi S (1995) Species composition of sand flies and population dynamics of Phlebotomus papatasi (Diptera: Psychodidae) in the southern Jordan Valley, an endemic focus of cutaneous leishmaniasis. J Med Entomol 32:822-6

9. Kanani K, Amr ZS, Shadfan B, Al-abdallat M (2015) Recent collection of sand flies of the genus Phlebotomus (Diptera: Psychodidae) from Jordan, with a checklist of previous records. Jordan J Biol Sci 8:193-7

10. Kanani K, Sheikh Ali SA, Shadfan B (2016) Gap analysis of leishmaniasis detection, prevention response: lessons learned of vectorborne diseases in the Hashemite Kingdom of Jordan. Poster presented at IMED International Meeting on Emerging diseases and Surveillance, Vienna, Austria

11. Koltas IS, Eroglu F, Alabaz D, Uzun S (2014) The emergence of Leishmania major and Leishmania donovani in southern Turkey. Trans R Soc Trop Med Hyg 108:154-8. doi: 10.1093/trstmh/ trt119. Epub 2014 Jan 20

12. Özkeklikçi A, Karakuş M, Özbel Y, Töz S (2017) The new situation of cutaneous leishmaniasis after Syrian civil war in Gaziantep city, Southeastern region of Turkey. Acta Trop 166:35-8. doi: 10.1016/j.actatropica.2016.10.019. Epub 2016 Oct 29

13. Salam N, Al-Shaqha WM, Azzi A (2014) Leishmaniasis in the Middle East: incidence and epidemiology. PLOS Neglected Tropical Diseases 8:e3208

14. Sharara SL, Kanj SS (2014) War and infectious diseases: challenges of the Syrian Civil War. PLoS Negl Trop Dis 8:e3208. doi: 10.1371/journal.pntd.0003208. eCollection 2014 Oct

15. Salman IS, Vural A, Unver A, Sacar S (2014) Cutaneous leishmaniasis cases in Nizip, Turkey after the Syrian civil war. Mikrobiyol Bul 48:106-13 [article en turc]

16. Saroufim M, Charafeddine K, Issa G, et al (2014) Ongoing epidemic of cutaneous leishmaniasis among Syrian refugees, Lebanon. Emerg Infect Dis 20:1712-5. doi: 10.3201/eid2010.140288

17. Tayeh A, Jalouk L, Cairncross S (1997) Twenty years of cutaneous leishmaniasis in Aleppo, Syria. Trans R Soc Trop Med Hyg 91:657-9

18. Turan E, Yeșilova Y, Sürücü HA, et al (2015) A comparison of demographic and clinical characteristics of Syrian and Turkish patients with cutaneous leishmaniasis. Am J Trop Med Hyg 93:559-63. doi: 10.4269/ajtmh.15-0090. Epub 2015 Jun 15 